\title{
Business Stealing And Bankruptcy
}

Linus Wilson, University of Louisiana at Lafayette, USA

\begin{abstract}
Mankiw and Whinston (1986) demonstrated that increased competition does not necessarily raise welfare when firms incur entry costs. Bankruptcy courts could have a role in discouraging overinvestment by their enforcement of financial contracts. The courts can move a homogenous goods industry closer to the social optimum by lowering the debt capacity and thereby increasing the taxable income of potential entrants. Further, it has been shown that exit is often insufficient in homogenous goods industries. This paper considers how bankruptcy courts can sometimes increase ex post social surplus by shutting down positive net present value firms.
\end{abstract}

\section{INTRODUCTION}

e ncreased competition does not always raise welfare. Competition gives rise to two externalities. A given firm raises its own profits by taking away some of the profits of rival firms. This is the "business stealing effect." Generally, competition is seen as beneficial because it entails another externality. Competition raises consumer surplus. The latter externality always is more potent than the first when firms have no fixed costs. Yet, when setup costs are positive, there is no guarantee that increased competition raises total welfare. Indeed, under very bland assumptions, Mankiw and Whinston (1986) show that free entry of firms unambiguously reduces welfare when producers have homogenous products and face positive entry costs. Excessive entry incentives are exacerbated by insufficient exit incentives. Given that any firms decide to exit, Wilson (2008) shows that strictly too few firms exit in the homogenous goods industry. This paper considers how bankruptcy courts could most effectively reduce the excessive entry and insufficient exit problems of Mankiw and Whinston (1986) and Wilson (2008). The author knows of no other study that has considered how bankruptcy courts could help overinvestment problems in homogenous goods industries.

This paper is unique in that it considers how bankruptcy courts could de facto regulate both entry and exit in an industry. In this paper, it is assumed that there is no regulator controlling entry, but the courts may be able to speed the exit of firms and may be able to affect the enforcement of financial contracts. This is motivated by the idea that judicial regulation may be preferable to all other feasible regulatory regimes. Nevertheless, regulated entry has a major disadvantage relative to a bankruptcy regime that considers the excessive entry problem. When bankruptcy judges shape the industry, they have the benefit of history. It is said that "hindsight is 20/20." While this may not always be the case, at least hindsight generally benefits from more information than forecasting. When regulators try to determine entry initially, they must make decisions with a great deal of uncertainty. They must make regulatory decisions before the features of the market and the profitability of individual firms are known. Bankruptcy courts, because they are looking back in time, have a better idea of the production conditions governing the industry than a regulator who is peering into the future. This idea that ex post regulation by the courts is preferable to ex ante entry regulation is pursued more formally in the appendix.

Judicial regulation has the most promise in industries where the products are close substitutes and are not traded internationally. Governments tend to be concerned almost exclusively with their own citizens' welfare and place little weight on the welfare of the citizens of another political jurisdiction. Therefore, judicial regulation will not only have little impact but also little political support in large global commodity markets like wheat and copper. In contrast, domestic airline travel is not traded internationally and has domestic ownership restrictions. Airlines in the United States may suffer from too much entry and excessive continuance. Further, these firms often find themselves filing for Chapter 11. This paper lends support to judges who are inclined to push troubled carriers towards liquidation as well as weaker enforcement of the absolute priority rules in those bankruptcy proceedings. 
This study has some commonalities with Cestone and White (2003) and many recent empirical studies of how financial intermediaries affect entry and thus the level of competition in the industry. ${ }^{1}$ Like these studies we argue that entry is regulated by how many firms can finance their entry into the market. In contrast, here it is the enforcement ex post of financial contracts through the bankruptcy courts, not competition among the suppliers of credit, banks and equity investors, which affects the equilibrium entry and exit in the industry. Further, unlike these studies that generally assume that more vigorous product market competition increases welfare, here we focus on the case where the duplication of fixed costs is more harmful than the gains from increased competition.

If courts aim to maximize social welfare, we argue that firms will trade off the potential costs of "inefficient liquidation" with potential benefits of reduced taxes. Debt saves money on taxes. Therefore, shareholders would trade the tax advantages of debt against the bankruptcy cost, which is endogenous to our argument here.

The extra bankruptcy cost imposed by courts may reduce investment, but it increases before tax expected profits and total welfare generated by the industry. We assume that entrants only differ in the magnitude of their initial investment. Courts that liquidate economically profitable firms may increase total welfare ex post and improve ex ante investment incentives. Moreover, absolute priority rule (APR) violations may indirectly induce firms to pay more taxes in expectation, reducing the marginal incentive to invest. In these ways, the courts can help correct the overinvestment problems in a homogeneous goods industry.

If the bankruptcy courts engage in ex post regulation of the industry and make the liquidation decisions in light of overall welfare, ex post and ex ante welfare will be weakly improved. There are limits to how much entry can be regulated by liquidating economically profitable firms. Increasing the exit rate of firms probably will not totally solve the excessive entry problem by itself. Therefore, we show that APR violations that give equity investors returns in bankruptcy can lead to the first-best level of investment as long as the corporate tax rate is sufficiently high.

The author knows of no study that has considered how debt and taxes can affect this excessive entry equilibrium. Nevertheless, there is a large literature on how capital structure and the enforcement of financial contracts affects the level of competition in an industry. Theoretical studies such as Allen (2000), Brander and Lewis (1986), Brander and Lewis (1988) ${ }^{1}$, and Maksimovic (1988) argue that debt increases product market competition. In contrast to the present paper, these studies have generally taken the number of competitors as given. Here, the number of entrants is endogenous and determined by free entry. Moreover, here there are no assumed barriers to entry. Also many of these other theoretical studies are in conflict with empirical work by Opler and Titman (1994), Chevalier (1995a), Chevalier (1995b), Phillips (1995), and Kovenock and Phillips (1997) that find that highly leveraged competitors are slower to expand output and invest. In this study, debt reduces taxes and makes entry more attractive; but, for some liquidation values, this leads to some highly leveraged, high-liquidationvalue competitors exiting when they would earn higher returns from staying in the industry. Therefore, it is largely consistent with the empirical studies, which say that highly leveraged firms are more likely to contract output. One way to contract output is to exit the industry. With judicial regulation it is shown that highly leveraged "risky debt" firms will sometimes be liquidated with low demand realizations, while "safe debt" firms will never be liquidated and thus will always compete.

\footnotetext{
${ }^{1}$ There are several recent empirical studies of how financial intermediaries affect the entry and competition in product markets. Strahan and Cetorelli (2006) find that concentrated bank ownership correlates with less competitive product markets. Bertrand, Schoar, and Thesmar (2007) argue that deregulation in the French banking sector both increased entry into product markets and accelerated the exit of inefficient firms. Cetorelli (2004) finds non-financial firms are smaller in countries where the banking sector is more competitive. Bonaccorsi di Patti and Dell'Arricca (2004) argue that competitive banking sectors only increase entry when firms products are well known, but, when the firms are more opaque, bank credit declines with the competitiveness of the financial sector.
} 


\begin{tabular}{|c|c|c|}
\hline $\begin{array}{l}\text { Period 0: } \\
\text { Entry and Capital Structure }\end{array}$ & $\begin{array}{l}\text { Period 1: } \\
\text { Bankruptcy and Reorganization }\end{array}$ & $\begin{array}{l}\text { Period 2: } \\
\text { Production }\end{array}$ \\
\hline $\begin{array}{l}\text { - A continuum of firms } \\
\text { sequentially enter and choose } \\
\text { their debt-to-equity ratio. The } \\
\text { ordering of entry is randomly } \\
\text { determined. } \\
\text { - Entry and capital structure } \\
\text { decisions are immediately } \\
\text { public knowledge to all } \\
\text { potential entrants. }\end{array}$ & $\begin{array}{l}\text { a. State of demand is revealed as either } \\
\text { high or low to all players. } \\
\text { b. The random ordering of exit } \\
\text { revealed. } \\
\text { c. Firms sequentially decide to exit or } \\
\text { compete in period two. The } \\
\text { ordering of exit and all exit or } \\
\text { compete decisions are public } \\
\text { knowledge. } \\
\text { d. Current shareholders decide whether } \\
\text { or not to enter bankruptcy court or } \\
\text { pay creditors in full in period } 2 . \\
\text { Bankruptcy court decides whether or } \\
\text { not to liquidate the bankrupt firm. If } \\
\text { the firm is allowed to operate, then } \\
\text { the court reallocates cash flow rights } \\
\text { between current shareholders and } \\
\text { creditors. }\end{array}$ & $\begin{array}{l}\text { - Firms } \\
\text { compete. } \\
\text { - Profits are } \\
\text { returned to } \\
\text { investors. }\end{array}$ \\
\hline
\end{tabular}

Figure 1: Sequence of Events

\section{MODEL}

Firms are identical, but they differ in their initial investment to enter the industry. Firms are ordered by their fixed costs of entry, $N$, on a continuous interval from $[0, \infty)$. Firms enter in a random order. The $N^{0}$-th firm is defined as the highest $N$ firm to enter the industry. The $N$-th firm must invest $I(N)$ in period 0 to enter the market and compete in the second period of the game. The investment is continuously increasing in the firm's rank, $N$.

That is, $\frac{d I(N)}{d N}>0$. Further, $I(N) \geq 0$ for all $N$.

Firms can recover a fraction, $\gamma$, of their period 0 investment, $I(N)$, where $0<\gamma<1$, if they shut down in period 2. Therefore, since the $N^{0}$-th firm made the largest investment, it has the greatest total value of non-specific assets, $\gamma I\left(N^{0}\right)$. In this model, the marginal $N^{0}$-th entrant has the least to gain from entering the industry and the most to gain from exiting it. This will become very important as we discuss capital structure choice.

Wilson (2009) proves that the ordering of entry and exit is irrelevant when firm size approaches zero. In particular, that paper shows in such a game, if the highest $N$ entrant is $N^{0}$, then all firms with a rank on the interval 0 $\leq N \leq N^{0}$ will enter. Wilson (2009) proves that all firms with $N \geq N^{0}$ in this game will also stay out. ${ }^{2}$

At the time of entering, the founding shareholders can determine the new firm's debt-to-equity ratio. The founding, period 0 , shareholders decide on how the claims to period 2 cash flows are to be divided between debt and equity holders in period 2. By assumption, these claims are only altered if the firm ends up in bankruptcy court in period 1e. That is, capital structure decisions are sticky, and renegotiation of ownership claims is prohibitively

\footnotetext{
${ }^{2}$ For the purposes of using calculus, we will treat $N$ as a continuous variable. Nevertheless, it is often useful to think of the number of firms as a non-negative integer. Amir and Lambson (2003) for example, solves a game with a non-negative integer number of firms. That is, the number of firms in the industry in that paper takes on the values $0,1,2, \ldots$
} 
costly outside of bankruptcy court. In summary, the entry and capital structure decisions of lower ranked firms can be taken as given by higher ranked firms. ${ }^{3}$

Suppose that there are two states, high and low. That is, $s=H$ or $L$. The probability of the high demand state is $h$ where $0 \leq h \leq 1$. In the high demand state, consumers are willing to pay a higher price for every quantity sold to the market.

$N^{s}$ is the number of firms operating in period 2 in the state of demand $s$. Firms choose output in period 2 after the state of demand has been revealed. ${ }^{4}$ By assumption, no firms are able to enter after the state is revealed because there are lags between the initial investment and a firm's ability to bring its product to market. In particular, no new firms can enter after period 0 .

At the start of period 1, period $1 a$, all players find out whether or not the state of demand is high or low. The ordering of exit is revealed in period $1 b$. The ordering of exit is random. Then, in period $1 c$, firms sequentially choose to exit. The exit decisions are sequential and are observed by all players. Wilson (2009) proves that in such a game the highest opportunity or fixed cost firms will exit when there is a continuum of firms. In period $1 d$ shareholders decide to renegotiate claims in bankruptcy court or are forced into bankruptcy court by unpaid creditors. In period $1 e$ the bankruptcy court reallocates cash flow rights and decides whether or not to liquidate the firm.

It is useful here to distinguish between liquidation decisions made by courts and liquidation decisions made by the period 1c shareholders of the debtor firm. The indicator variable $\theta(N)$, which denotes whether or not the firm is liquidated in the low demand state, can be rewritten as the following:

$\theta(N)=\max \{\theta(c, N), \theta(d, N)\}$,

Above " $c$ " denotes the liquidation decision taken by the courts and " $d$ " denotes the liquidation decision made by controlling investors of the debtor firm. For example, when the firm does not enter bankruptcy court in the low demand state, $\theta(c, N)=0$, because the courts do not have an opportunity to liquidate. The courts make liquidation decisions in period $1 e$ to maximize $e x$ ante welfare in the industry where the industry welfare function is given in equation (19) of the appendix. In contrast, liquidation decisions are made by period $1 c$ shareholders who want to maximize their returns.

It is assumed that firms are controlled to maximize the returns to the current generation of shareholders. Therefore, future generations of shareholders may find it optimal to take actions that strictly lower ex ante value if it leads to higher returns ex post. In this model, there is one action that is dynamically inconsistent from the perspective of period 0 shareholders. Namely, period $1 d$ shareholders can choose to enter bankruptcy court to renegotiate their claims with bondholders. (Renegotiations are assumed to be impossible outside of bankruptcy court.) Therefore, shareholders suffer from the inability to commit not to renegotiate inside bankruptcy.

In this presentation, we rely on Gertner and Scharfstein (1991)'s observation that debt restructurings often fail. ${ }^{5}$ We assume that all out-of-court restructurings fail with a probability 1 . If we relaxed this assumption, firms

\footnotetext{
${ }^{3}$ Suppose that the bankruptcy court's strategy would be to liquidate the firm $N^{*}$ if it entered bankruptcy court. The sticky capital structure choice is a commitment to stay in the industry in a given state if firm $N^{*}$ does not take on too much debt or to exit the industry if firm $N^{*}$ takes on a lot of debt.

${ }^{4}$ In contrast, Brander and Lewis (1986), Brander and Lewis (1988), Glazer (1994) and Faure-Grimaud (2000), assume that firms choose outputs before the state of the world is revealed. Therefore, in the Brander and Lewis (1986) paper, firms will engage in the "risk-shifting" as described by Jensen and Meckling (1976). This is when equity has an incentive to increase the risk of the cash flows by a more aggressive output stance because it only gets paid in high demand realizations. The present paper assumes that output decisions are made after the state of demand is realized. For this reason, in the present paper, capital structure does not affect the output decisions of firms in the market. Capital structure in this paper only has an indirect effect on competition by its influence on the number of competitors entering and staying in the market.

${ }^{5}$ In practice troubled firms suffer from several problems when pursuing exchange offers where debt claims are swapped for equity to avoid a bankruptcy filing. Gertner and Scharfstein (1991) point out that from 1977 to 1990 only 73 of 156 financially
} 
would choose higher levels of debt on average, and inefficient liquidations by the courts would become more unlikely as the probability that troubled firms could restructure their debt out-of-court increases. This would hamper the courts' ability to speed exit in the industry.

In contrast, we assume that it is the courts' objective to maximize total ex ante welfare. We also assume that courts can commit to maximize ex ante welfare even though they must act ex post. In practice, this latter assumption is not as crucial as one would suspect initially because Wilson (2008) proves that there is little conflict between ex post and ex ante welfare. In the context of homogeneous goods industries, Wilson (2008) shows that this means discouraging the duplication of fixed costs and encouraging the redeployment of assets outside the industry, and increasing before-tax profits in the industry.

The courts can also reduce entry ex ante by facilitating absolute priority rule (APR) violations ex post. APR violations lower the debt capacity of the marginal entrant and increase the taxes that must be paid in expectation. Suppose that the courts only are willing to pay non-equity investors a fraction of the returns in a given state. Let $0 \leq a^{L} \leq 1$ and $0 \leq a^{H} \leq 1$, where $a^{s}$ is the maximum fraction of revenues minus variable costs that the courts will award to holders of debt in a given state. In addition, let us assume that the APR violation depends on the type, $N$, of the firm and whether or not it takes on safe or risky debt. That is, if $\delta=f$ or $r$. That is $a^{L}=a^{L}(N, \delta)$ and $a^{H}=a^{H}(N, \delta)$. A fall in alpha improves equity's ex post bargaining position with respect to its lenders in a given state. Therefore, equity and its agents will always extract a fraction of the returns, $\left(1-a^{s}(N, \delta)\right)$, by undertaking strategic default.

In fact, courts will find it difficult to violate the priority of secured lenders. Lenders who have been awarded durable assets in the event of default can reasonably expect to recover most, if not all, of their claims. ${ }^{6}$ Therefore, the minimum percent of assets that courts will award ex post to bondholders, as opposed to shareholders, must be in the following ranges, depending on the state and on the equilibrium liquidation decisions:

$$
\begin{aligned}
& 1 \geq \alpha^{L}(N, \delta) \geq(1-\theta(N)) \frac{\gamma I(N)}{\pi\left(L, N^{L}\right)}+\theta(N) \\
& 1 \geq \alpha^{H}(N, \delta) \geq \frac{\gamma I(N)}{\pi\left(H, N^{H}\right)}
\end{aligned}
$$

The scrap value of the firm, $\gamma I(N)$, may or may not exceed the going concern value of the firm in the low demand state, $\pi\left(L, N^{L}\right)$. Therefore, the courts may or may not be able to violate priority in the low demand state. Nevertheless, for any given entrant, it is impossible that the scrap value exceeds the going concern value of the firm in the high demand state. Otherwise, it would be unprofitable for that firm to enter. Therefore, the courts always weakly have the scope to violate priority in the high demand state.

distressed junk bond issuers successfully completed exchange offers. They say that one reason for this is the "holdout" problem. The holdout problem stems from the fact that creditors who do not swap their claims for equity see the value of their claims rise as costly bankruptcy is avoided. The holdout problem means that creditors who fail to tender free ride off those who do. This problem may be especially acute the United States, for example. The Trust Indenture Act requires that there must be unanimous consent before the interest, principal, or maturity of any public debt issue is changed. This means that each creditor must agree individually for any exchange where the creditor receives equity for debt, making the free rider problem almost unavoidable.

${ }^{6}$ Here we are arguing that the lower bound of the courts' discretion to violate priority is bounded by the proportion of assets that are durable. This seems reasonable, but sometimes courts even dissipate or divert the value of secured claims. For example, secured creditors are stayed from seizing assets in U.S. Chapter 11, which are deemed essential for the running of the business by the bankruptcy court. Eastern Airlines' bankruptcy may be an extreme example of how the automatic stay can be abused. According to Weiss and Wruck (1998), only 38 percent of asset sales were distributed to debt holders during and after Eastern Airlines' prolonged stay in Chapter 11 bankruptcy and its eventual shutdown on January 19, 1991. The assumption that secured claims are 100 percent secure as in (2) and (3) may be extreme. For example, Bris, Welch, and Zhu (2006) in a study of small and large bankruptcies in Arizona and New York state, find that secured creditors lose assets to unsecured creditors in roughly 20 percent of the cases. It may be more reasonable to conclude that the courts' discretion to violate priority is decreasing in the percent of assets that a durable, $\gamma$. 
The potential for APR violations in the high demand state makes "strategic default" profitable to shareholders ex post. Here, strategic default occurs when the equity-controlled firm enters bankruptcy protection in period $1 d$ to avoid paying creditors the full promised value of the debt in period 2. In particular, default is "strategic" in the sense that the firm would be able to pay debt holders in full in that state of demand.

The life of the industry is compressed into period 2 where firms operate from time 0 beginning in the start of period 2 to time infinity at the end of period 2. This infinite period structure allows the firm to deduct all payments to bondholders. If the debt is perpetual, all payments can be interest, which is tax deductible.

For simplicity, bankruptcy occurs in period $1 e$ after the state of demand is revealed in period $1 a$, prior to production taking place in period 2. This way, the industry benefits from firms exiting. In practice, bankruptcy is often postponed until default is almost imminent. Therefore, there may be a span of time where "zombie" competitors drive down prices in the industry prior to exiting.

After the state is revealed and liquidation decisions are made, all firms are identical competitors. They produce the same output and earn identical profits before fixed costs of $\pi\left(s, N^{s}\right)$. Pi above stands for per-firm producer surplus, not economic profit. (Economic profit includes fixed costs.) We will assume that per-firm producer surplus is increasing in the state. That is, the equilibrium output response leads to rising per-firm producer surplus for a given industry size. That is, for any given industry size $N^{*}, \pi\left(H, N^{*}\right)>\pi\left(L, N^{*}\right){ }^{7}$ Further, per-firm producer surplus is declining in the number of competitors $\frac{d \pi\left(s, N^{s}\right)}{d N^{s}}<0$. This is consistent with the predictions of the Cournot model, for example.

A firm will only enter an industry if it can recover the expected cost of its investment after corporate taxes. The marginal corporate tax rate is $\tau$, where $0<\tau \leq 1$. In addition, we will assume that investors pay no personal taxes. ${ }^{8}$ Further, we will assume for simplicity that the tax shields from depreciation are zero. Therefore, total returns to the founding shareholders are the period 0 cash flows from issuing debt and the period 2 profits after taxes and debt payments.

The firm is owned by founding shareholders who set capital structure in period 0 to maximize the value of their shares. All investors are risk neutral. For simplicity, we will assume that the risk free rate of interest is zero in period 0 and period 1. In period 2, the risk free rate of interest is $\rho>0$ in the infinite number of production subperiods in period 2. Debt holders are price takers and will supply funds if they can merely recover the cost of their investment in expectation. The debt pays a coupon interest of $C \geq 0$ in each sub-period of period 2. The debt is perpetual. Interest payments are tax deductible. If all promised payments are made, the discounted value of the debt is denoted $F \equiv C / \rho$. We will call this the promised value of the debt. (This infinite sub-period structure in period 2 allows firms to deduct the full value of their debt from corporate taxes because interest but not principal is tax deductible. In practice, most firms issue finite maturity debt, but continue to refinance the debt, thus making the interest payments effectively perpetual and allowing managers to maintain a target debt-to-value ratio.) The returns from asset sales and production respectively are realized in small increments of each one of the infinite sub-periods

\footnotetext{
${ }^{7}$ All the output, price, and per-firm producer surplus assumptions are consistent with an industry composed of Cournot competitors facing a linear inverse demand curve.

${ }^{8}$ Miller (1977) says that the gain from leverage is reduced because the personal income tax rate paid on interest income from investors holding debt exceeds the personal income tax rate from holding shares. That paper says that Modigliani and Miller (1963) only applies when personal taxes on debt are equal to the personal taxes from holding shares. This is not the case in the United States. The top tax rates on capital gains and dividends, $\tau_{p S}$, as of January 2006 were 15 percent. Compare this to 35 percent from income on the interest from debt. The marginal corporate tax rate for corporations with large amounts of taxable income is 35 percent. If we assume that capital gains are realized immediately and the marginal investor for the firm's equity and the aggregate debt market was in the top tax bracket, the Miller (1977) equation would argue that the gain from debt would be $G=\left(1-\frac{(1-\tau)\left(1-\tau_{p S}\right)}{1-\tau_{p B}}\right) B=\left(1-\frac{(1-.35)(1-.15)}{1-.35}\right) B \approx .15 B<.35 B$, where .35B is the gain indicated by Modigliani and Miller (1963).
} Graham (2000) estimates that the gains are positive, but they are much less than indicated by Modigliani and Miller (1963) because firms often do not get to use their full interest deductions. 
within period 2. Each period 2 sub-period return is equal to $\rho \gamma I(N)$ if the firm is liquidated or $\rho \pi\left(s, N^{s}\right)$ if the firm competes in period 2. The present value of these returns is $\gamma I(N)$ and $\pi\left(s, N^{s}\right)$, respectively, at the start of periods 0 , 1 , or 2 .

The maximum allowable tax deduction that a firm can make will equal the ex post investment returns of that firm in a given state. Therefore, if $F \geq \gamma I(N)$, when the firm is liquidated, or if $F \geq \pi\left(s, N^{s}\right)$, when the firm operates in state $s$, then the $N$-th firm gets to deduct up to $\tau \gamma I(N)$ or $\tau \pi\left(s, N^{s}\right)$, respectively, from its tax bill.

We will assume that there is only one class of bondholders. Bondholders' claims are always senior to shareholders' claims. Control is not automatically given to bondholders in default. Control of the firm rests with shareholders prior to default and with the court in period $1 e$ when default is certain to occur in period 2. All uncertainty is resolved in period 1. If the promised value of the debt is high enough, then default will be certain. Bondholders are only given control of the firm at the court's discretion after the firm has entered bankruptcy.

Shares have limited liability. Therefore, the minimum payoff in period 2 is zero. Taxes due are reduced by the payments to creditors. The expected payments to creditors in period 0 is denoted $B$ or $B^{\delta}$. The promised value, $F$ or $F^{\delta}$, is due in period 2 after production takes place. Let the superscript $\delta$ take on two values $\delta=f$ or $r$. Risk-free debt has no default risk. We will denote risk free debt by the superscript " $f$." With risk-free debt, the promised value and the value of the debt is equal to $F^{f}=B^{f}$, regardless of the period or the state. The founding shareholders can also sell risky debt, which is denoted by the superscript " $r$." With risk-free debt, shareholders can always optimally control whether or not the firm is liquidated in the low demand state. With risky debt the courts have the discretion to liquidate the $N$-th firm.

\section{ANALYSIS}

Under fairly weak assumptions there is excessive entry in homogenous product industries. This was proved by Mankiw and Whinston (1986). In addition, Wilson (2008) shows that exit is insufficient in these industries in the absence of taxation. Here, we will argue that if the courts liquidate some economically profitable firms, they will raise welfare ex post and ex ante. In this section, founding shareholders trade off the risks of inefficient liquidation (costly bankruptcy) for lower taxation of corporate profits. The higher, before-tax, industry profits generated by liquidating economically profitable firms will more than offset the losses to consumers and the losses to investors in the liquidated firms. Moreover, by invalidating some of shareholders' promises to creditors in bankruptcy by means of absolute priority rule (APR) violations, courts can lower the debt capacity of firms entering the industry. Lower debt capacities mean that firms pay more taxes in expectation, which further discourages entry. These policies may improve investment incentives; nevertheless, there is no guarantee that they will lead to the optimal level of entry and exit.

The continuation objectives of judges and holders of risky debt are in conflict when $\gamma I(N)<\pi\left(L, N^{L}\right)$. That is, the judge liquidates economically profitable firms where $\pi\left(L, N^{L}\right)>\gamma I(N)$. This is the "interesting case" with which we are most concerned. When judges liquidate a firm that could earn $\pi\left(L, N^{L}\right)$ in excess of the firm's liquidation value, $\gamma I(N)$, then we say that firm $N$ has been inefficiently liquidated.

If founding shareholders of the $N$-th firm intend to enter, they will also structure debt claims in a way that maximizes the value of their shares. Suppose that investors in the $N$-th firm expect the court to inefficiently liquidate it if default is imminent. If $\gamma I(N)<\pi\left(L, N^{L}\right)$, in equilibrium, and courts pursue inefficient liquidation, then the value function jumps at the point where debt becomes risky because the low state returns are less than if the firm had no risky debt.

The potential for strategic default reduces the value of the debt that the firm can issue. Moreover, given that courts commit to not liquidate firms in the high demand state, ${ }^{9}$ APR violations reduce the maximum returns that

\footnotetext{
${ }^{9}$ If the firm is liquidated in the high state, then the shareholders get nothing, but if the firm is allowed to continue, they get $1-$ $a^{H}(N, \delta)$ of the returns. By committing to allow the firm to continue debt capacity is reduced. If high state involuntary liquidations in bankruptcy would occur, period 1 shareholders would have no incentive for strategic default.
} 
bond holders can expect in the high state by $\left(1-a^{H}(N, \delta)\right) 100$ percent. In order that safe debt be truly safe, founding shareholders will also reduce the promised value of safe debt by the percent of low state returns that shareholders can win by strategic default in the low state.

If the firm issues safe debt, the maximum promised value of safe debt will be a function of the absolute priority violations, $a^{L}(N, f)$ and $a^{H}(N, f)$, and whether or not the firm is (optimally) liquidated, $\theta(d, N)=1$, in the low demand state:

$$
\begin{aligned}
& F^{f}(N) \equiv B^{f}(N) \equiv \\
& \min \left\{\alpha^{L}(N)(1-\theta(d, N)) \pi\left(L, N^{L}\right)+\theta(d, N) \gamma I(N), \alpha^{H}(N) \pi\left(H, N^{H}\right)\right\} .
\end{aligned}
$$

The value of the $N$-th firm is denoted by $V^{\Theta}\left(N, F^{\delta} ; a^{L}(N, \delta), a^{H}(N, \delta)\right)$. The superscript of $\theta=0$ or 1 indicates whether the firm continues to operate or is liquidated in the low demand state, respectively. The first argument denotes the rank of the firm. The second argument, in part, denotes both the size of the promised value, and whether or not the debt is safe or risky. The third and fourth arguments are the level of absolute priority that will be respected by the courts in a given state for the $N$-th firm with safe or risky debt firm. Let us find out what is the maximum value of the firm, given that it takes on safe debt:

$$
\begin{aligned}
& \underset{\text { w.r.t. } F, \theta(N, d)}{\arg \max } V^{\theta}\left(N, F^{f} ; \alpha^{L}(N, f), \alpha^{H}(N, f)\right) \text {, where } \\
& V^{\theta}\left(N, F ; \alpha^{L}(N, f), \alpha^{H}(N, f)\right)=\tau F+(1-\tau) h \pi\left(H, N^{H}\right) \\
& +(1-\tau)(1-h)\left\{(1-\theta(N, d)) \pi\left(L, N^{L}\right)+\theta(N, d) \gamma I(N)\right\}-I(N), \\
& \text { and } F \leq F^{f}(N) .
\end{aligned}
$$

This value function in equation (5) is maximized when the safe debt firm takes on the upper limit of safe debt. As with Modigliani and Miller (1963), firm value is maximized when the upper limit of debt is chosen. That is $F^{r}(N)$ given by equation (4). following:

The maximum value of the $N$-th safe debt firm that will be liquidated in the low demand state is the

$$
\begin{aligned}
& V^{1}\left(N, F^{f} ; \alpha^{L}(N, f), \alpha^{H}(N, f)\right) \\
& =\tau \gamma I(N)+\left\{(1-\tau)\left[h \pi\left(H, N^{H}\right)+(1-h) \gamma I(N)\right]-I(N)\right\} .
\end{aligned}
$$

When the period $1 c$ shareholders decide upon liquidation $\theta(d, N)=1$, the debt that maximizes the value of the firm given that the firm has safe debt is $F^{f}=\gamma I(N)$.

The maximum value of a safe debt firm that continues to operate in the low demand state is

$$
\begin{aligned}
& V^{0}\left(N, F^{f} ; \alpha^{L}, \alpha^{H}\right)= \\
& \tau \min \left[\alpha^{L}(N, f) \pi\left(L, N^{L}\right), \alpha^{H}(N, f) \pi\left(H, N^{H}\right)\right] \\
& +\left\{(1-\tau)\left[h \pi\left(H, N^{H}\right)+(1-h) \pi\left(L, N^{L}\right)\right]-I(N)\right\} .
\end{aligned}
$$

The terms in \{\} in (7) is the value of the unlevered firm. The first term on the LHS of (7) is the value of leverage, which is tax rate times the value of the risk free bonds.

Suppose that the $N$-th firm is a risky debt firm. APR violations reduce debt tax shields by $\tau\left(1-a^{H}(N\right.$, $r)) \pi\left(H, N^{H}\right)$ in the high state and $\tau(1-\Theta(N))\left(1-a^{L}(N, r)\right) \pi\left(L, N^{L}\right)$ in the low state if the firm continues. (From (2), the courts cannot reduce tax shields in the low demand state if the firm is liquidated in the low demand state.) Ideally, in a risky debt firm, shareholders receive their whole payoff in period 0 . This allows them to avoid 
corporate taxes. Yet, if they get part of the returns in period 2, these earnings are taxable. Therefore, the firm's expected value is reduced by the extra taxes levied on equity investors. Given that the firm has risky debt shareholders will want to maximize the value of the firm with respect to the promised value of the debt and the liquidation decision, $\theta(d, N)$ :

$$
\begin{aligned}
& \underset{\text { w.r.t. } F, \theta(N, d)}{\arg \max } V^{\theta}\left(N, F^{r} ; \alpha^{L}(N, r), \alpha^{H}(N, r)\right), \text { where } \\
& V^{\theta}\left(N, F^{r} ; \alpha^{L}(N, r), \alpha^{H}(N, r)\right)=\tau h \min \left\{\alpha^{H}(N) \pi\left(H, N^{H}\right), F\right\}+ \\
& \tau(1-h) \min \left\{\left[(1-\theta(N)) \alpha^{L}(N, r) \pi\left(L, N^{L}\right)+\theta(N) \gamma I(N)\right], F\right\} \\
& +(1-\tau) h \pi\left(H, N^{H}\right)+(1-\tau)(1-h)\left\{(1-\theta(N)) \pi\left(L, N^{L}\right)+\theta(N) \gamma I(N)\right\}-I(N),
\end{aligned}
$$

Let us denote the maximum value of the risky debt firm of rank $N$, which will be liquidated in the low state, as $V^{1}\left(N, F^{r} ; \alpha^{L}(N, r), \alpha^{H}(N, r)\right)$ :

$$
\begin{aligned}
& V^{1}\left(N, F^{r} ; \alpha^{L}(N, r), \alpha^{H}(N, r)\right)= \\
& {\left[\tau h \alpha^{H}(N, r) \pi\left(H, N^{H}\right)+\tau(1-h) \gamma I(N)\right]} \\
& +\left\{(1-\tau)\left[h \pi\left(H, N^{H}\right)+(1-h) \gamma I(N)\right]-I(N)\right\}
\end{aligned}
$$

\section{Lemma 1}

Given that the marginal entrant chooses risky debt and is liquidated in the low demand state, its entry decision is unaffected by the profits in the low-demand state.

The proof of this is intuitive and follows from equation (9). In equation (9), the profits from competing in the low demand state, $\pi\left(L, N^{L}\right)$, do not enter into the payoff of the $N$-th firm. Therefore, the payoff to the marginal entrant, firm $N^{H}$, is also unaffected by the low demand state profits. Q.E.D. This explains why there is often no conflict between maximizing welfare in period 0 and maximizing welfare in period 2 . The marginal entrant does not care about the low state operating profits because it only operates in the high demand state.

The maximum value of a risky debt firm that will not be liquidated is denoted by

$$
\begin{aligned}
& V^{0}\left(N, F^{r} ; \alpha^{L}(N, r), \alpha^{H}(N, r)\right): \\
& V^{0}\left(N, F^{r} ; \alpha^{L}(N, r), \alpha^{H}(N, r)\right)= \\
& {\left[\tau h \alpha^{H}(N, r) \pi\left(H, N^{H}\right)+\tau(1-h) \alpha^{L}(N, r) \pi\left(L, N^{L}\right)\right]} \\
& +\left\{(1-\tau)\left[h \pi\left(H, N^{H}\right)+(1-h) \pi\left(L, N^{L}\right)\right]-I(N)\right\}
\end{aligned}
$$

Likewise, when the firm optimally chooses safe debt, the expected value of the firm is reduced by the increased taxes caused by the lower expected value of the debt in the low state. It is at least weakly in period 0 shareholders' interest to only sell debt with a promised value equal to (4). Any higher promised value would put the firm at the mercy of the courts. Given that safe debt strictly increases the ex ante value of the firm, liquidation in the low demand state is more costly than continuation, $\gamma I(N)<\pi\left(L, N^{L}\right)$. Otherwise, the firm would have chosen the higher tax shields of risky debt. Founding shareholders in period 0 will want to prevent period $1 d$ shareholders from triggering a strategic default (and court induced liquidation in period 1e). ${ }^{10}$ Therefore, founding shareholders need to ensure that the payoffs to the current shareholders in a given state will always weakly exceed the gains from strategic default in that state.

\footnotetext{
${ }^{10}$ The court does not have to have the authority to mandate liquidation. Instead, shifting control of the firm to a secured creditor group, which would be in favor of liquidation, will lead to the firm being liquidated in bankruptcy court.
} 
To see if an individual firm will favor risky or safe debt or vice versa, we can subtract equation (9) from equation (7). If the relationship is positive, the $N$-th firm will prefer safe debt. If the relationship is negative, it will prefer risky debt. This lax enforcement of the absolute priority of claims reduces the ex ante value of debt by the before-tax value of returns that are awarded to equity. Yet, when equity gets returns in bankruptcy, these returns are taxed. On balance, the value of the firm is reduced. Moreover, the firm will have a greater equity-to-value ratio after bonds are sold, relative to strict APR enforcement of debt covenants.

\section{Proposition 1}

Period 0 shareholders will never strictly prefer safe debt if the firm if period 1c shareholders would liquidate the firm in the low demand state.

To prove this let us compare equations (6) and (9). Equation (6) is the maximum value of a safe debt firm that period 1 shareholders choose to liquidate the firm in period 1. Equation (9) is the maximum value of a safe debt firm that is liquidated by period $1 c$ shareholders. Subtracting equation (9) from equation (6) we get the following:

$$
\begin{aligned}
& V^{1}\left(N, F^{f} ; \alpha^{L}(N, f), \alpha^{H}(N, f)\right)-V^{1}\left(N, F^{r} ; \alpha^{L}(N, r), \alpha^{H}(N, r)\right) \\
& =\tau h\left[\gamma I(N)-\alpha^{H}(N, r) \pi\left(H, N^{H}\right)\right] \leq 0 .
\end{aligned}
$$

We know that the lower bound of $a^{H}(N, r) \pi\left(H, N^{H}\right)$ is $\gamma I(N)$ from equation (3). Therefore, the firm is always weakly more valuable if period 0 shareholders sell risky debt, given that period $1 c$ shareholders will liquidate the firm in the low demand state. Q.E.D.

The social planner attempting to reach the optimal level of entry and exit through the courts faces the following problem:

$\arg \max \quad W\left(N^{H}, N^{L}\right)$

w.r.t. $\quad N^{H} \& N^{L}$

We will denote the first-best number of competitors in the high and low demand state respectively as $N^{H^{*}}$ and $N^{L^{*}}$. Mankiw and Whinston (1986) and Wilson (2008) prove that $N^{H^{*}}$ and $N^{L^{*}}$ are often strictly lower than the number of competitors under free entry and exit.

The courts don't control entry and exit directly, but they do control APR violations and liquidation decisions in bankruptcy, $\theta(c, N)$. Therefore, the courts' problem is to maximize the objective function in (12) with respect to $N^{H}$ and $N^{L}$ subject to three constraints on $N^{H}$ and $N^{L}$. These constraints are given by equations (13), (14), and (15) below. Let us define a column vector $\mathbf{a}_{\mathbf{N}}$ that denotes the level of priority that the courts will choose for a given firm rank $(N)$, state $(H$ or $L)$, and type of debt $(\delta=f$ or $r)$. That is, $\mathbf{a}_{\mathbf{N}}=\left\{a^{L}(N, f), a^{H}(N, f), a^{L}(N, r), a^{H}(N, r)\right\}$. Further, their control over $\mathbf{a}_{\mathbf{N}} \forall N \in\left[0, N^{H}\right]$ are given by equations (2) and (3).

The following must be true of any equilibrium:

$$
\begin{gathered}
\text { (1) } N^{H} \geq N^{L}, \\
\underset{\delta, \theta(d, N)}{\arg \max } V^{\theta}\left(N, F^{\delta} ; \alpha^{L}, \alpha^{H}\right) \geq 0 \forall N \in\left[0, N^{H}\right], \\
\text { (2) } E^{\theta}\left(\alpha^{L}, \alpha^{H}\right) \equiv \underset{\delta, \theta(d, N)}{\arg \max } V^{\theta}\left(N^{H}, F^{\delta} ; \alpha^{L}, \alpha^{H}\right)=0,
\end{gathered}
$$

and

$$
\underset{\delta, \theta(d, N)}{\arg \max } V^{\theta}\left(N, F^{\delta} ; \alpha^{L}, \alpha^{H}\right)<0 \forall N \in\left(N^{H}, \infty\right) .
$$


The set of conditions above says firstly that the number of firms in the low demand state cannot exceed the number of entrants. All entrants must be making positive, after-tax profits, given their capital structure, $\delta$, and liquidation decisions, $\theta(d, N)$, are optimally chosen. Then, the marginal entrant must make exactly zero after-tax net returns. That is, the entry constraint, $E^{\theta}\left(\alpha^{L}, \alpha^{H}\right)$, in (14) must equal zero. Finally, no $N>N^{H}$ firms must enter.

In many cases, the marginal entrant will have safe debt, $\delta=f$, because the courts commit to the maximum absolute priority violations. That is $B^{f}=F^{f}=\gamma I\left(N^{H}\right)$. Nevertheless, the firms will optimally be liquidated in the low demand state. That is, $\theta(d, N)=1$ because $\pi\left(L, N^{L}\right)<\gamma I\left(N^{H}\right)$. Therefore, when the courts can violate priority, in many instances the marginal entrant will be forced to have safe debt.

APR violations make the firm pay more corporate taxes in expectation. Lower APR violations or higher alphas make the firm more valuable in expectation and make more firms enter. If possible, $a^{s}(N, \delta)$ would be chosen such that either $N^{H^{*}}$ firms enter. Yet, this is only is possible if the constraints 1 and 2 in (13) and (14) are met, given the constraints on $a^{s}(N, \delta)$. This is the case where the first order condition of welfare with respect to $N^{H}$ equals zero. Alternatively, the maximum set of APR violations is chosen for the $N^{H}$-th firm. That is, $\left\{a^{L}\left(N^{H}, \delta\right), a^{H}\left(N^{H}, \delta\right)\right\}$ will be the lower bounds of equations (2) and (3) if entry is excessive. If first-best entry is achievable, for example, the courts will want to choose a set of alphas- $\left\{a^{L}\left(N^{H^{*}}, \delta\right), a^{H}\left(N^{H^{*}}, \delta\right)\right\}$ - for the marginal entrant such that (14) binds for firm $N^{H^{*}}$.

Let us consider a third constraint, the "risky debt constraint." It says that all firms that will be liquidated in the low state with risky debt must prefer risky debt over safe debt and no liquidation. This is a particularly interesting problem when $\Theta(d, N)=0$. Otherwise, it is easily satisfied. The risky debt constraint (3) is the following in the interesting case where firms may not want to be liquidated in the low demand state:

$$
\begin{aligned}
& R(N ; \mathbf{a}) \equiv \\
& V^{0}\left(N, F^{f} ; \alpha^{H}(N, f), \alpha^{L}(N, f)\right)-V^{1}\left(N, F^{r} ; \alpha^{H}(N, r), \alpha^{L}(N, r)\right) \leq 0, \\
& \forall N \in\left(N^{L}, N^{H}\right] .
\end{aligned}
$$

Taking taxes as given, equation (15) will most likely be satisfied when the courts select the lower bounds of equations (2) and (3) when a firm takes on safe debt and continues to operate in period 2.

$$
\begin{aligned}
& \underset{\alpha^{L}(N, f), \alpha^{H}(N, f)}{\arg \min } V^{0}\left(N, F^{f} ; \alpha^{L}(N, f), \alpha^{H}(N, f)\right) \\
& =\tau \gamma I(N)+\left\{(1-\tau)\left[h \pi\left(H, N^{H}\right)+(1-h) \pi\left(L, N^{L}\right)\right]-I(N)\right\},
\end{aligned}
$$

Further, by completely respecting priority and thus selecting the upper bound of (3), the courts can make risky debt and inefficient liquidation more attractive. In such a case, an involuntarily liquidated firm will be worth the following:

$$
\begin{aligned}
& \underset{\alpha^{L}(N, r), \alpha^{H}(N, r)}{\arg \max }\left\{V^{1}\left(N, F^{r} ; \alpha^{L}(N, r), \alpha^{H}(N, r)\right) \mid \theta(c, N)=1\right\} \\
& =h \pi\left(H, N^{H}\right)+(1-h) \gamma I(N)-I(N) .
\end{aligned}
$$

Generally, treating different firms differently will best accomplish the goals of minimizing entry and encouraging welfare-increasing exit. Suppose that $N^{H}>N^{H^{*}}>N^{L^{*}}$. The marginal entrant and all higher $N$ firms can face the maximum high state APR violation. This minimizes entry. This is most easily accomplished when the marginal entrant chooses risky debt even when the lower bounds of (2) and (3) are selected by the courts. If the marginal entrant chooses risky debt, then it will not care about the fact that profits are higher in the low demand state due to forced liquidations. Yet, this only can occur when the marginal entrant is more valuable if it liquidates itself in the low demand state. This is the case when $\pi\left(L, N^{L}\right)<\gamma I\left(N^{H}\right)$, and $\Theta(d, N)=0$. 
To minimize entry in this case, the courts can encourage as many firms as possible to take on risky debt. To best accomplish this, the courts can minimize the value of shareholders' choices in period 0 and period $1 c$ of $\delta=$ $f$ and $\theta(d, N)=0$, respectively. This is the minimization problem in equation (16). This is accomplished by choosing $\alpha^{L}(N, f)=\frac{\gamma I(N)}{\pi\left(L, N^{L}\right)}$, and $\alpha^{H}(N, f)=\frac{\gamma I(N)}{\pi\left(H, N^{H}\right)}$. Further, the courts can maximize the value of being a risky debt firm that is liquidated as in equation (17). They do this by setting $a^{H}(N, r)=1$. The courts need to commit to these policies for all firms on the interval $\left(N^{L}, N^{H}\right)$.

In some instances, there may be a conflict between discouraging entry and encouraging the marginal firm to take on risky debt. Suppose that the court cannot convince the marginal entrant to take on risky debt when APR violations are at their maximum as in the lower bound of equations (2) and (3). Further suppose that entry is excessive, $N^{H}>N^{H^{*}}$. In this case, it may be possible to convince the non-marginal entrants of rank $N<N^{H}$ to take on risky debt. Nevertheless, encouraging the non-marginal entrants to take on risky debt and to be involuntarily liquidated makes entry more attractive as profits in the low state rise with fewer $N^{L}$. Wilson (2007, pp. 346-351) shows that, when the marginal entrant chooses safe debt, it is ambiguous whether or not welfare maximizing courts will choose to liquidate any firms in the low demand state.

We can think of the problem of selecting the levels of APR violations as a constrained optimization problem. The social planner operating through the courts will want to adjust the size of the industry at two points. First, the number of firms entering in period 0 should only be $N^{H^{*}}$. Second, in the low state ideally $N^{L^{*}}$ firms will remain after liquidations. We know from Wilson (2008)'s proposition 2, that some of those liquidations will have to be involuntary if $N^{H^{*}}>N^{L^{*}}$. If the courts are going to be able to achieve the second objective, two things must happen. First, only $N^{H^{*}}$ must voluntarily enter the industry. Second, firms of index numbers $N \geq N^{L^{*}}$ must voluntarily choose to take on risky debt. In practice, it may be very hard to get a firm of rank $N \geq N^{L^{*}}$ to voluntarily risk inefficient liquidation.

Consider the following proposition.

\section{Proposition 2}

Given that the corporate tax rate, $\tau$, is sufficiently high and the proportion of durable investments, $\gamma$, is sufficiently low, APR violations can move the homogenous product industry to the efficient level of investment.

Suppose that the corporate tax rate, $\tau$, is 100 percent. The maximum APR violations are bounded by the proportion of durable investments in equations (2) and (3). Therefore, when $\gamma=0$, the APR violation can be 100 percent of the returns in a given state. The net loss of tax shields can equal the total increase in returns to shareholders ex post if both the APR violation and the corporate tax rate are 100 percent. In this case, no firm would enter if investment costs $I(N)>0$. Since Mankiw and Whinston (1986) proved that entry is excessive in absence of taxes, there must exist some intermediate fractions $a^{L}\left(N^{H^{*}}\right)$ and $a^{H}\left(N^{H^{*}}\right)$ that induces the ex ante efficient level of investment in the industry.

Courts can solve the insufficient exit problem of Wilson (2008) when fixed assets have no resale value. This is the case when $\gamma=0$. When $N^{H^{*}}>N^{L^{*}}$ and firms are very dependent on tax shields, the courts can encourage the efficient level of exit. When taxes are 100 percent and the courts are unconstrained in violating priority ex post, the courts can select a vector $\mathbf{a}_{\mathbf{N}}=\left\{a^{L}(N, f), a^{H}(N, f), a^{L}(N, r), a^{H}(N, r)\right\}$ for each and every firm on the interval $\left(N^{L^{*}}\right.$, $N^{H^{*}}$ ] such that these firms' founding shareholders will prefer inefficient liquidation in the low demand state to having lower tax shields in the high demand state. Q.E.D.

The final proposition shows that judicial regulation as posed here may be too weak relative to entry restrictions when taxes are low and when courts have trouble ignoring firms' promises to creditors.

The first part of the appendix discusses why ex post regulation by the courts may be preferable to entry restrictions in curbing excess entry. Courts can regulate the industry with hindsight, while a regime of entry 
restrictions must be able to accurately predict the prospects for the industry before a firm has entered. Venture capitalists, who have strong incentives to guess right, struggle with forecasting the profitability and size of the industries of the future. The author is skeptical that government regulators with weaker incentives to accurately predict the size and scope of an industry can do a good job with regulating entry. Courts acting at the death of firms (or at least midlife of firms) have the benefit of making their decisions later than a regulator who makes decisions at a firm's birth.

\section{CONCLUSION}

There are good reasons to believe that many industries are plagued by overinvestment, not underinvestment. Potential firms ignore both the positive externality to consumers of increased competition and the negative externality of lower industry profits. The latter externality is called the "business stealing" effect. If firms face setup costs and produce identical goods, Mankiw and Whinston (1986) illustrate that duplicated fixed costs and business stealing will outweigh the benefits from increased consumer surplus.

When entry is excessive, courts can have a role in pushing the industry to the welfare maximizing level of investment. Here, we argue that bankruptcy courts can shape the industry through their enforcement of financial contracts. In this context, actions that discourage investment and push profitable firms to exit may actually raise aggregate welfare.

There are two ways that courts can discourage investment. First, they can increase bankruptcy costs by encouraging the liquidation of economically profitable firms. Second, if courts can reduce the debt capacity of potential entrants, they can increase firms' tax burdens and lower firms' after-tax returns. Debt capacity is reduced not only by increasing the costs of bankruptcy but also by predictable absolute priority rule (APR) violations that would lead to shareholders appropriating returns from bondholders ex post. Less debt capacity means higher taxes paid and lower after-tax returns.

Courts may not be able to move the industry to its welfare maximizing size. They are limited by how much they can reduce debt tax shields through APR violations. Further, they can only liquidate firms that choose to take on risky debt. In general, higher corporate tax rates aid the courts in reducing investment because they make tax shields and risky debt more important. The first-best may not be achievable, but the courts sometimes can make Pareto improvements by liquidating economically profitable firms and giving shareholders a slice of the returns when the firm defaults.

The author believes this is the first study to relate the problem of excessive entry to judicial decisions in bankruptcy. In practice, entry into most industries is not regulated by the government directly. Instead, entry is regulated by the willingness of investors to supply investment funds. Creditors, both in principle and in practice, are rarely in control of the firms under which their claims are written. These creditors are dependent on public and private enforcement of contracts. When bankruptcy judges are likely to ignore some contracts, this tendency will make potential lenders much less likely to supply funds.

We have argued here that sometimes a little inefficiency may be a good thing. Nevertheless, careful attention would have to be paid to the unique nature of the industry before we can conclude that welfare will be raised by courts that actively try to discourage investment and/or liquidate profitable firms.

\section{AUTHOR INFORMATION}

Linus Wilson is an assistant professor of finance. He joined the University of Louisiana at Lafayette in fall 2007. His research interests are in corporate finance and industrial organization. He has written papers on CEO pay, capital structure in professional partnerships, industrial market structure, entrepreneurship, and mutual funds. Prior to coming to Lafayette, he has taught at the University of Cincinnati and the University of Oxford. He received his Doctor of Philosophy in economics at the University of Oxford for his thesis Essays on the Financial Governance of Firms in 2007. 


\section{REFERENCES}

1. Allen, F., 2000, "Capital Structure and Imperfect Competition in Product Markets," in Peter J. Hammond and Gareth D. Myles eds., Incentives, Organization, and Public Economics: Papers in Honor of Sir James Mirrlees, Oxford, England: Oxford University Press, 281-301.

2. Amir, R., and V. E. Lambson, 2003, "Entry. Exit, and Imperfect Competition in the Long Run,” Journal of Economic Theory, 110, 191-203.

3. Bertrand, M., A. S. Schoar, and D. Thesmar, 2007, "Banking Deregulation and Industry Structure: Evidence from French Banking Reforms of 1985," Journal of Finance, 62, 597-628.

4. Bonaccorsi di Patti, E., and G. Dell'Ariccia, 2004, "Bank Competition and Firm Creation," Journal of Money, Credit, and Banking, 36, 225-51.

5. Brander, J. A., and T. R. Lewis, 1986, "Oligopoly and Financial Structure: The Limited Liability Effect," American Economic Review, 76, 956-970.

$6 . \quad-\quad-1988$, "Bankruptcy Costs and the Theory of Oligopoly," Canadian Journal of Economics, 21, 221-243.

7. Bris, A., I. Welch, and N. Zhu, 2006, “The Costs of Bankruptcy: Chapter 7 vs. Chapter 11 Reorganization," Journal of Finance, 61, 1253-1303

8. Cestone, G., and L. White, 2003, "Anti-competitive Financial Contracting: The Design of Financial Claims," Journal of Finance, 58, 2109-42.

9. Cetorelli, N., 2004, "Real Effects of Bank Competition," Journal of Money Credit and Banking, 36, 54358.

10. Chevalier, J., 1995a, "Capital Structure and Product Market Competition: Empirical Evidence from the Supermarket Industry," American Economic Review, 85, 415-35.

11. - ------, 1995b, "Do LBO Supermarkets Charge More? An Empirical Analysis of the Effects of LBOs on Supermarket Pricing," Journal of Finance, 50, 1095-1112.

12. Faure-Grimaud, A., 2000, "Product Market Competition and Optimal Debt Contracts; The Limited Liability Effect Revisited," European Economic Review, 44, 1823-1840.

13. Gertner, R., and D. Scharfstein, 1991, "A Theory of Workouts on the Effects of Reorganization Law," Journal of Finance, 46, 1189-1222.

14. Glazer, J., 1994, "The Strategic Effects of Long-Term Debt in Imperfect Competition," Journal of Economic Theory, 42, 428-443.

15. Graham, J., 2000, "How Big are the Tax Advantages from Debt," Journal of Finance, 55, 1901-1942.

16. Jensen, M. C., and W. H. Meckling, 1976, "Theory of the Firm: Managerial Behavior, Agency Costs, and Ownership Structure," Journal of Financial Economics, 3, 305-306.

17. Kovenock, D., and Phillips, G. M., 1997, "Capital Structure and Product Market Behavior: An Examination of Plant Exit and Investment Decisions," Review of Financial Studies, 10, 767-803.

18. Maksimovic, V., 1988, "Capital Structure in Repeated Oligopoly," RAND Journal of Economics, 3, 389407.

19. Mankiw, G., and M. D. Whinston, 1986, "Free Entry and Social Inefficiency," Rand Journal of Economics, $17,48-58$.

20. Miller, M. H., 1977, "Debt and Taxes," Journal of Finance: Papers and Proceedings, 32, 261-275.

21. Modigliani, F., and M. H. Miller, 1963,"Corporate Income Taxes and the Cost of Capital: a Correction," American Economic Review, 53, 433-443.

22. Opler, T. C., and S. Titman, 1994, "Financial Distress and Corporate Performance," Journal of Finance Papers and Proceedings, 49, 1015-1040.

23. Phillips, G. M., 1995, "Increased Debt and Industry Product Markets an Empirical Analysis," Journal of Financial Economics, 37, 189-238.

24. Strahan, P. E., and N. Cetorelli, 2006, "Finance as a Barrier to Entry: Bank Competition and Industry Structure in Local US Markets," Journal of Finance, 61, 437-61,

25. Weiss, L. A., and K. H. Wruck, 1998, "Information Problems, Conflicts of Interest, and Asset Stripping: Chapter 11's Failure in the Case of Eastern Airlines," Journal of Financial Economics, 48, 55-97.

26. Wilson, L., 2007, Essays on the Financial Governance of Firms, D.Phil. thesis, University of Oxford.

27. ---------, 2008, "Free Exit and Social Inefficiency," Working Paper, University of Louisiana at Lafayette. 
28. - -------- 2009, "Fixed Cost Efficiency with Infinitesimal Competitors," forthcoming Applied Economics Letters.

\section{APPENDIX}

\section{Judicial Regulation v. Entry Restrictions}

Here we argue that regulating the industry by means of bankruptcy courts, "judicial regulation," may be preferable to setting entry restrictions. Judicial regulation benefits from the fact actions are taken ex post. This means that much of the uncertainty concerning industry conditions has been resolved. There are two types of uncertainty. First, there is uncertainty about the period 0 expected welfare generated by the industry. Let us call this $\sigma$-uncertainty. Second, there is uncertainty about the evolution of the industry in period $1 a$. Let us call this $s$ uncertainty. Judicial regulation has the benefit of acting after both these uncertainties are resolved. Nevertheless, bankruptcy courts cannot affect entry directly. Therefore, entry restrictions may raise welfare relative to judicial regulation when there is little uncertainty, taxes are low, and courts have little scope to give ex post returns to equity.

Suppose that bankruptcy courts operate in period $1 e$, but entry restrictions must be set in period -1 before firms enter. From the perspective of period $1 e$, the bankruptcy courts will be in a better position to calculate period 0 expected welfare than a regulator who is trying to forecast demand and production conditions in a period -1 .

Further, bankruptcy courts regularly are asked to make judgments about the value of distressed firms and to make decisions that may impede or speed up the liquidation of these over levered firms. Wilson (2008) shows that there will be weakly too little exit in the low demand state. Entry restrictions cannot encourage firms to exit in the low demand state, but bankruptcy courts can push firms to liquidate.

Suppose there is a period -1 where the social planner can either choose to regulate the industry through a period -1 , ex ante entry restriction or through period 1 e, ex post regulation by bankruptcy courts. The entry restriction chooses a number of entrants, $N^{R}$, which is ex ante optimal from the perspective of period -1 . Alternatively, she can organize the scheme of judicial regulation as described here. The social planner has beliefs about the expected welfare, $W_{\sigma}\left(N^{H}, N^{L}\right)$ generated by the industry. Expected welfare in period -1 is a function of $\sigma$, which is drawn from a continuous support $(\underline{\sigma}, \bar{\sigma})$, and the density function, $f(\sigma)>0$, about the period 0 welfare function generated by the industry. In period $1 e$, both $\sigma$ and $s$ are known to the social planner and to the bankruptcy courts, acting on her behalf. That is, bankruptcy courts can benefit from the option to "wait and see" how demand and industry conditions evolve up to the point where a firm lands up in court. The entry restriction, in contrast, must be set before the realization of both $\sigma$ and $s$ are known. By choosing a regime of judicial regulation, one gets a set of high and low state industry sizes $\left\{N_{J \sigma}^{H}, N_{J \sigma}^{L}\right\} \forall \sigma$, where $N_{J \sigma}^{s}$ is the subgame perfect Nash equilibrium size of the industry under judicial regulation, subscript "J", for a given set of states $\{\sigma, s\}$. Let $N^{R}$ be the maximum number of entrants permitted by the social planner in period -1. With period -1 an entry restriction, one gets a set of high and low state industry sizes $\left\{\min \left(N^{R}, N_{U \sigma}^{H}\right), \min \left(N^{R}, N_{U \sigma}^{L}\right)\right\} \forall \sigma$, where $N_{U \sigma}^{s}$ is the subgame perfect Nash equilibrium industry size in an unregulated industry, subscript " $U$," for the given set of states $\{\sigma, s\}$. Judicial regulation will be chosen when

$$
\begin{aligned}
& \int_{\underline{\sigma}}^{\bar{\sigma}} f(\sigma) W_{\sigma}\left(N_{J \sigma}^{H}, N_{J \sigma}^{L}\right) d \sigma \geq \\
& \quad \int_{\underline{\sigma}}^{\bar{\sigma}} f(\sigma) W_{\sigma}\left(\min \left\{N^{R}, N_{U \sigma}^{H}\right\}, \min \left\{N^{R}, N_{U \sigma}^{L}\right\}\right) d \sigma .
\end{aligned}
$$

Judicial regulation by benevolent courts will weakly dominate an entry restriction for all states where the entry restriction did not bind. This is when $N^{R}>N_{U \sigma}^{s}$. Moreover, it seems that judicial regulation would be preferred to an entry restriction as the density function, $f(\sigma)$, became more diffuse. Indeed, judicial regulation may 
be preferred when there is no period $-1, \sigma$-uncertainty! This is because judicial regulation also gets to adjust for period $1, s$-uncertainty. If we drop the sigma notation, this is the case when

$W\left(N_{J}^{H}, N_{J}^{L}\right) \geq W\left(\min \left\{N^{R}, N_{U}^{H}\right\}, \min \left\{N^{R}, N_{U}^{L}\right\}\right)$.

Yet, entry restrictions may dominate judicial regulation when the industry conditions are stable and judges are tightly constrained. (For example when there is no uncertainty, entry restrictions will be first-best. $N^{R}=N^{H^{*}}=$ $N^{L^{*}}$.) In proposition 2, we find that bankruptcy courts have the least power to shape the industry when assets are durable ( $\gamma$ is close to one) and the marginal corporate tax rate is low ( $\tau$ is close to zero.) Therefore, if the tools of bankruptcy courts are weak, then judicial regulation, with all its informational advantages, may be dominated by a regime of entry restrictions.

\section{The Welfare Function} following:

To define aggregate welfare it is useful to decompose the per-firm producer surplus function into the

$\pi\left(s, N^{s}\right) \equiv P\left(s, Q^{s}\right) q\left(s, N^{s}\right)-c\left(q^{s}\left(s, N^{s}\right)\right)$

Let us discuss the components of equation (18) in turn.

As in Mankiw and Whinston (1986) and Wilson (2008) per-firm output, $q\left(s, N^{s}\right)$, is assumed to decline in the number of firms, $\frac{d q\left(s, N^{s}\right)}{d N}<0$. Further, an individual firm's output is increasing in the state. That is, $q\left(H, N^{\prime}\right.$ ) > $q\left(L, N^{\prime}\right)$ for any given $N^{\prime}$.

Aggregate industry output is the number of firms, $N^{s}$, producing individual output $q^{s} \equiv q\left(s, N^{s}\right)$. In short, aggregate output is $Q^{s} \equiv N^{s} q^{s}$. As with Mankiw and Whinston (1986) and Wilson (2008), industry output is assumed to rise with the number of firms competing in the state $\frac{d Q^{s}}{d N}>0$.

The inverse demand schedule given by $P\left(s, Q^{s}\right)$ is a function of the state, $s$, and of aggregate output, $Q^{s}$, of the firms competing in the state. More output in a given state means lower prices $\frac{d P}{d Q^{s}}<0$. The market price is increasing in the state. That is, $P\left(H, Q^{\prime}\right)>P\left(L, Q^{\prime}\right)$ for a given $Q^{\prime}$.

One justification for firms producing identical outputs is that we are assuming they have symmetric variable cost functions, $c\left(q^{s}\right)$. The firms face constant or decreasing returns to scale. That is, $c^{\prime}(q) \geq 0$, and $c^{\prime \prime}(q) \geq 0$. Further, let $c(0)=0$.

With the decomposition in equation (18) aggregate welfare can be defined below. Aggregate welfare is the area under the inverse demand function, $P\left(s, Q^{s}\right)$, minus the variable costs of production in each state, $N^{s} c\left(q^{s}\right)$, weighted by the probability of each state plus the recovery value of the assets of the exiting firms, $\gamma I(N)$, that are liquidated in the low demand state weighted by the probability of the low demand state less the costs of entry, $I(N)$, for all the firms. 


$$
\begin{aligned}
& W\left(N^{H}, N^{L}\right)=h\left[\int_{0}^{N^{H} q^{H}} P(H, v) d v-N^{H} c\left(q^{H}\right)\right] \\
& +(1-h)\left[\int_{0}^{N^{L} q^{L}} P(L, v) d v-N^{L} c\left(q^{L}\right)+\gamma \int_{N^{L}}^{N^{H}} I(u) d u\right]-\int_{0}^{N^{H}} I(u) d u
\end{aligned}
$$

In the case where no firms are liquidated $\left(N^{H}=N^{L}\right)$ in the low demand state, the welfare function is simply a function of the equilibrium number of entrants, ${ }^{11} N^{H}$ :

$$
\begin{aligned}
& W\left(N^{H}\right)=h\left[\int_{0}^{N^{H} q\left(H, N^{H}\right)} P(H, v) d v-N^{H} c\left(q^{H}\right)\right] \\
& +(1-h)\left[\int_{0}^{N^{H} q\left(L, N^{H}\right)} P(L, v) d v-N^{H} c\left(q^{L}\right)\right]-\int_{0}^{N^{H}} I(u) d u
\end{aligned}
$$

\section{NOTES}

${ }^{11}$ Wilson (2008)'s proposition 1 proves that no firm will enter if it plans to be liquidated in the high demand state. Therefore, the high demand state number of competitors is equal to the number of entrants. 
International Business \& Economics Research Journal - March 2009

Volume 8, Number 3

NOTES 